\title{
EFFECTIVENESS OF ACUPRESSURE ON REDUCING OF NAUSEA AND VOMITING IN PREGNANT WOMEN IN INDEPENDENT MIDWIFERY PRACTICE, SIDOARJO, EAST JAVA
}

\author{
Nanik Handayani \\ Faculty of Nursing and Midwifery, Universitas Nahdlatul Ulama Surabaya
}

\begin{abstract}
ABSTRAK
Background: During pregnancy, there can be various pregnancy complications, including nausea and vomiting, which is often experienced by pregnant women. This condition is one of the earliest symptoms of pregnancy. This nausea and vomiting are physiological. This physiological condition will turn into a pathology if not appropriately treated. This study aimed to analyze the effect of acupressure on reducing nausea and vomiting in pregnant women at the Sidoarjo midwife's independent practice.

Subjects and Method: This study is a quasi-experiment with pre and post-test control group design conducted at Midwife Independent Practice, Sidoarjo from April to September, 2020. The dependent variable was nausea and vomiting. The independent variable was acupressure. The population of all primigravida pregnant women who experience nausea and vomiting. A sample of 40 was divided into 20 given intervention and 20 as control selected by purposive sampling. The data were collected by acupressure SOP and questionnaire with a Score Pregnancy Unique Quantification of Emesis and or Nausea Scoring System (PUQE) assessment. The data were analyzed by Wilcoxon and Mann Whitney.

Results: The results showed that acupressure was effective in reducing nausea and vomiting in primigravida pregnant women $(\mathrm{OR}=19.00 ; 95 \% \mathrm{CI}=2.11$ to $5.13 ; \mathrm{p}=0.009)$.

Conclusion: Acupressure is effective in reducing nausea and vomiting in primigravida pregnant women.

Keywords: acupressure, pregnant women, nausea and vomiting

\section{Correspondence:}

Nanik Handayani. Faculty of Nursing and Midwifery, Universitas Nahdlatul Ulama Surabaya, East Java. Jl. Smea No 57 Surabaya. Email: nanik_handayani@unusa.ac.id. Mobile: 08123278582.
\end{abstract}

